\title{
The abnormal cytotoxic T cell response to Epstein- Barr virus in rheumatoid arthritis is correlated with disease activity and occurs in other arthropathies
}

\author{
J S H GASTON, A B RICKINSON, Q Y YAO, AND M A EPSTEIN \\ From the Department of Pathology, University of Bristol Medical School, Bristol
}

SUMmaRY The cytotoxic T cell response to Epstein-Barr virus as measured by the regression $\stackrel{\text { cे }}{\rightarrow}$ assay was found to be impaired in a group of patients with active rheumatoid arthritis (RA). When these patients responded clinically to treatment with sulphasalazine there was a concomitant increase in the strength of this virus specific $T$ cell response. The suggestion of a 0 correlation between disease activity and impairment in this immune response was borne out in studies of other groups of patients with RA. Thus six out of 10 hospitalised patients had abnormal $Z$ regression compared with six out of 31 patients seen routinely as outpatients. Studies of patients with inflammatory arthropathies other than RA, however, also showed abnormal regression in $\frac{\Phi}{5}$ four out of 16 patients. It is concluded that the impairment in the cytotoxic $\mathrm{T}$ cell response to $\stackrel{\mathbb{Q}}{-}$ Epstein-Barr virus in RA is influenced by disease activity, and that this abnormality is not $\stackrel{\oplus}{0}$ specific feature of rheumatoid disease.

Patients with rheumatoid arthritis (RA) show abnormal responses to infection by Epstein-Barr (EB) virus. Thus humoral responses are characterised by raised titres of antibodies to EB virus capsid, early and nuclear antigens, ${ }^{12}$ and by a higher incidence and titre of antibodies to the rheumatoid arthritis nuclear antigen (RANA). ${ }^{3-5}$ This last antigen is now believed to be identical to one of the EB virus encoded nuclear antigens. ${ }^{6}$

A number of abnormalities in the cellular response to EB virus have also been described. Firstly, normal adult $\mathrm{T}$ lymphocytes are able to delay the outgrowth of EB virus infected B cells in vitro through an interferon mediated mechanism, ${ }^{7}$ whereas $\mathrm{T}$ cells from patients with RA are deficient in this respect. ${ }^{89}$ Secondly, all healthy individuals previously infected with EB virus (EB virus seropositive) also possess circulating virus specific memory $\mathrm{T}$ cells with cytotoxic potential; such cells can be reactivated in cultures of virus infected peripheral blood mononuclear (PBM) cells, where their action

Accepted for publication 9 May 1986.

Correspondence to Dr J S H Gaston, Department of Rheumatology, The Medical School, University of Birmingham, B15 2TJ. prevents the outgrowth of a virus transformed B cell line. ${ }^{10-12}$ This latter immunological response can be $\mathbb{D}$ measured because abrogation of $B$ cell outgrowth (termed 'regression') is preferentially seen in more densely seeded cultures. Accordingly, the strength of the immune $\mathrm{T}$ cell response in a given individual can be expressed in terms of the initial number of PBM cells required for a $50 \%$ incidence of regression in replicate culture wells. ${ }^{13}$ This same cytotoxic $\frac{0}{\circ}$ $\mathrm{T}$ cell response may also be responsible for the 'late 3 suppression' of immunoglobulin production which is $\delta$ observed in cultures of EB virus infected PBM cells from virus immune donors. ${ }^{14}$

A previous study has shown that a significant proportion of patients with RA had a markedly abnormal cytotoxic response to EB virus as measured in the regression assay; ${ }^{15}$ late suppression of $\widetilde{N}$ immunoglobulin secretion is also impaired in RA. ${ }^{14} \mathrm{~N}$ The patients studied using the regression assay were $\mathrm{N}$ chosen since they had active RA. It is of interest, $\sigma$ therefore, to determine firstly, whether the abnormality is related to disease activity, and secondly, $\frac{0}{\Phi}$ whether it is only seen in RA or may also be $\stackrel{\oplus}{\mathcal{D}}$ observed in other inflammatory arthropathies. The present study addresses these questions. 


\section{Patients and methods}

\section{PATIENTS}

Four groups of patients were studied: (1) Fourteen outpatients (nine female, five male) drawn from a previous study, ${ }^{15}$ who had classical or definite $\mathrm{RA}^{16}$ and were considered on clinical grounds to require treatment with a 'disease modifying' drug. They were placed on therapy with sulphasalazine $(1 \mathrm{~g}$ daily) and were examined regularly to assess the activity of their RA using clinical and laboratory measurements. (2) Thirty one patients with classical or definite RA described in a previous study. ${ }^{17}$ (3) Seventeen patients (12 male, five female) with seronegative spondyloarthropathy (three with Reiter's syndrome, three with psoriatic arthropathy, and 11 with ankylosing spondylitis). (4) Fifteen patients with either osteoarthritis (12 patients) or gout (three patients).

Eleven of 14 patients in group 1 and 31 of 31 patients in group 2 were seropositive for IgM rheumatoid factor. Patients in all groups were receiving non-steroidal anti-inflammatory drugs. None of the patients in group 1 were receiving any disease modifying drug at the time of the initial study; nine had previously received such drugs but stopped them at least six weeks before the study (mean (SD) 19 (10) weeks). Two patients continued to take a small dose of prednisone (less than $5 \mathrm{mg}$ ).

No patients in groups 2 or 3 were receiving disease modifying drugs or steroids.

\section{CONTROLS}

These consisted of 52 healthy subjects drawn from laboratory personnel and normal blood donors.

\section{EB VIRUS SPECIFIC, T CELL MEDIATED I M M U N I T Y}

The in vitro regression assay was performed as previously described. ${ }^{15}$ Briefly, unfractionated mononuclear (UM) cells were seeded over a range of doubling dilutions in microtest plate wells immediately after their exposure to a potent EB virus preparation. The wells were observed carefully for the appearance of foci of EB virus transformed cells and their subsequent regression or outgrowth. The magnitude of the cytotoxic $T$ cell response is expressed in terms of the minimum number of UM cells required per well for a $.50 \%$ incidence of regression in replicate culture wells. Hence the lower the number of UM cells required, the stronger the regression response.

EB VIRUS SPECIFIC SEROLOGY

Antibody titres to the EB virus capsid antigen were measured by a standard technique. ${ }^{18}$
CLINICAL LABORATORY MEASUREMENTS Plasma viscosity, serum immunoglobulins, and $C$ reactive protein (CRP) were measured by standard techniques. The use of concanavalin $A$ binding to measure acute phase proteins has been described elsewhere. ${ }^{19}$

\section{S T A T I S T I C S}

Student's paired $t$ test was used as appropriate; correlation coefficients were calculated using 'Minitab' (Statistics Dept, Penn State University).

\section{Results}

Fig. 1 shows the results obtained when the strength

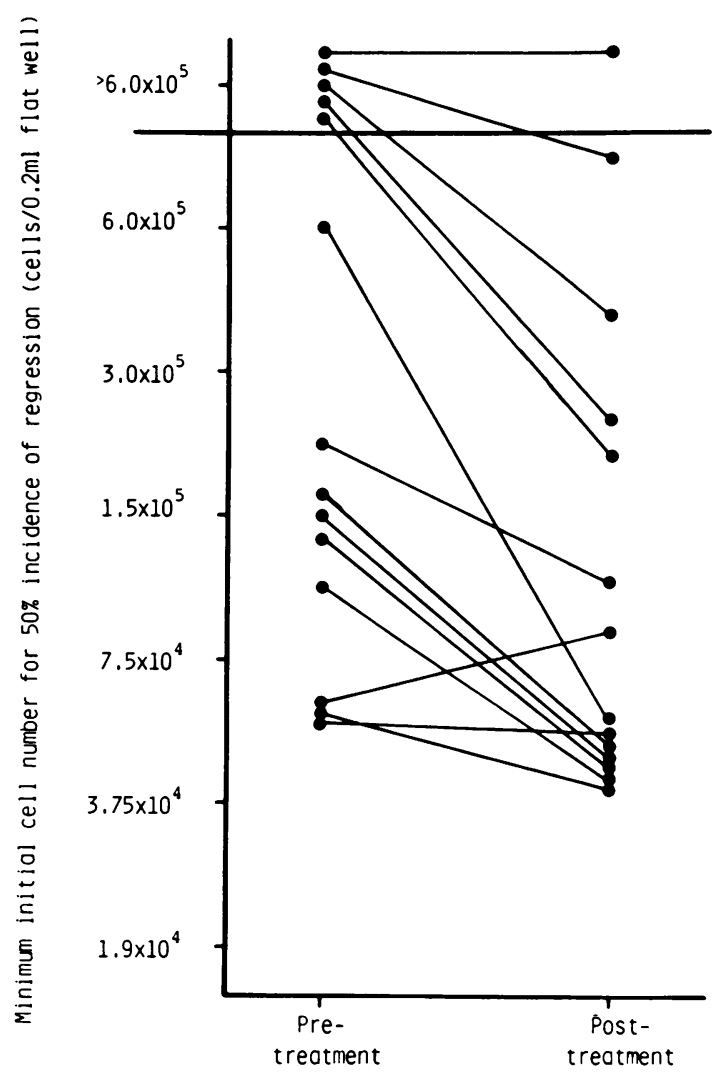

Fig. 1 Results of regression assays obtained from a group of patients with active $R A$ tested pre-and post-treatment with sulphasalazine. Results are expressed as the minimum initial number of UM cells per well required for a $50 \%$ incidence of regression among replicate culture wells. Thus high cell numbers reflect weak regression. (One patient, who had no detectable regression before treatment, had clear regression in two out of six of the wells seeded at the highest cell density after treatment, so that although a $50 \%$ end point was not achieved, this change is still indicated in the figure.) 
Table 1 Changes in parameters reflecting disease activity in a group of patients with active RA tested pre-and posttreatment with sulphasalazine

\begin{tabular}{|c|c|c|c|}
\hline & $\begin{array}{l}\text { Pre- } \\
\text { treatment }\end{array}$ & $\begin{array}{l}\text { Post- } \\
\text { treatment }\end{array}$ & p Value \\
\hline \multicolumn{4}{|l|}{ Early morning stiffness } \\
\hline Ritchie index & $20.4(10 \cdot 4)$ & $14 \cdot 8(8 \cdot 1)$ & $<0 \cdot 01$ \\
\hline Visual analogue $(\mathrm{cm})$ & $4 \cdot 6(3 \cdot 1)$ & $3.08(2.91)$ & $<0 \cdot 01$ \\
\hline \multirow{2}{*}{ Grip strength (mmHg) $R$} & $105 \cdot 9(27 \cdot 6)$ & $123 \cdot 3(40 \cdot 4)$ & $<0.02$ \\
\hline & $110 \cdot 1(34 \cdot 9)$ & $119 \cdot 9(44 \cdot 2)$ & $<0.02$ \\
\hline Plasma viscosity (cP) & $1 \cdot 86(0 \cdot 13)$ & $1 \cdot 69(0 \cdot 11)$ & $<0.001$ \\
\hline$C$ reactive protein $(\mathrm{g} / \mathrm{l})$ & $0.040(0.029)$ & $0.017(0.012)$ & $<0.001$ \\
\hline Con A binding $(g / 1)$ & $59 \cdot 7(13 \cdot 2)$ & $48 \cdot 4(13 \cdot 5)$ & $<0.001$ \\
\hline Immunoglobulins (g/l) & $32 \cdot 1(3 \cdot 6)$ & $28 \cdot 6(4 \cdot 1)$ & $<0.001$ \\
\hline
\end{tabular}

${ }^{*}$ Values are mean (SD).

of the cytotoxic $\mathrm{T}$ cell response to $\mathrm{EB}$ virus was measured, by the regression assay, in a group of 14 EB virus seropositive RA patients. The measurements were made initially when the patients had active arthritis on clinical and laboratory criteria, and subsequent to a period of treatment with sulphasalazine. Eleven patients were tested after three months' treatment and three after nine months' treatment. It can be seen that nine of the 14 patients showed an increase in the strength of their cytotoxic $\mathrm{T}$ cell response to $\mathrm{EB}$ virus. In particular, four patients, in whom no evidence of regression was detected initially, even at the highest density of cell seeding, had clearly detectable regression after treatment.

Table 1 indicates the changes in parameters reflecting disease activity over the same period for these 14 patients. It is clear that there was consistent evidence of improvement, especially in those indicators of the inflammatory response (plasma viscosity and acute phase reactants), but. also in clinical measurements. Indeed, each of these patients showed some evidence of a clinical response to sulphasalazine, though the extent of the response varied. These results seem to indicate a relation between disease activity in RA and the impairment of the cytotoxic $T$ cell response to $E B$ virus. In support of this notion, a weak but significant correlation was found between the strength of regression and the concentration of $\mathrm{C}$ reactive protein when the data from patients before and after treatment were combined $(r=0 \cdot 48, p=0.01)$.

To address the question of whether the abnormal response to $\mathrm{EB}$ virus is specifically related to $\mathrm{RA}$, further groups of patients were examined. Fig. 2 shows the strength of regression measured in 52 normal control subjects, 17 patients with an active spondyloarthropathy, 15 patients with osteoarthritis or gout, and a further group of 31 patients with RA. (The last group was unselected with regard to disease activity and represented a series of consecutive outpatients.) All 50 EB virus seropositive donors showed a $50 \%$ end point for the incidence of regression, which was within the range of mononueo lear cell seedings per culture employed in the regression assay; two EB virus seronegative donors showed no such response, emphasising the immunological specificity of the phenomenon. Four out of 16 EB virus seropositive patients with an active spondyloarthropathy showed the same absence of

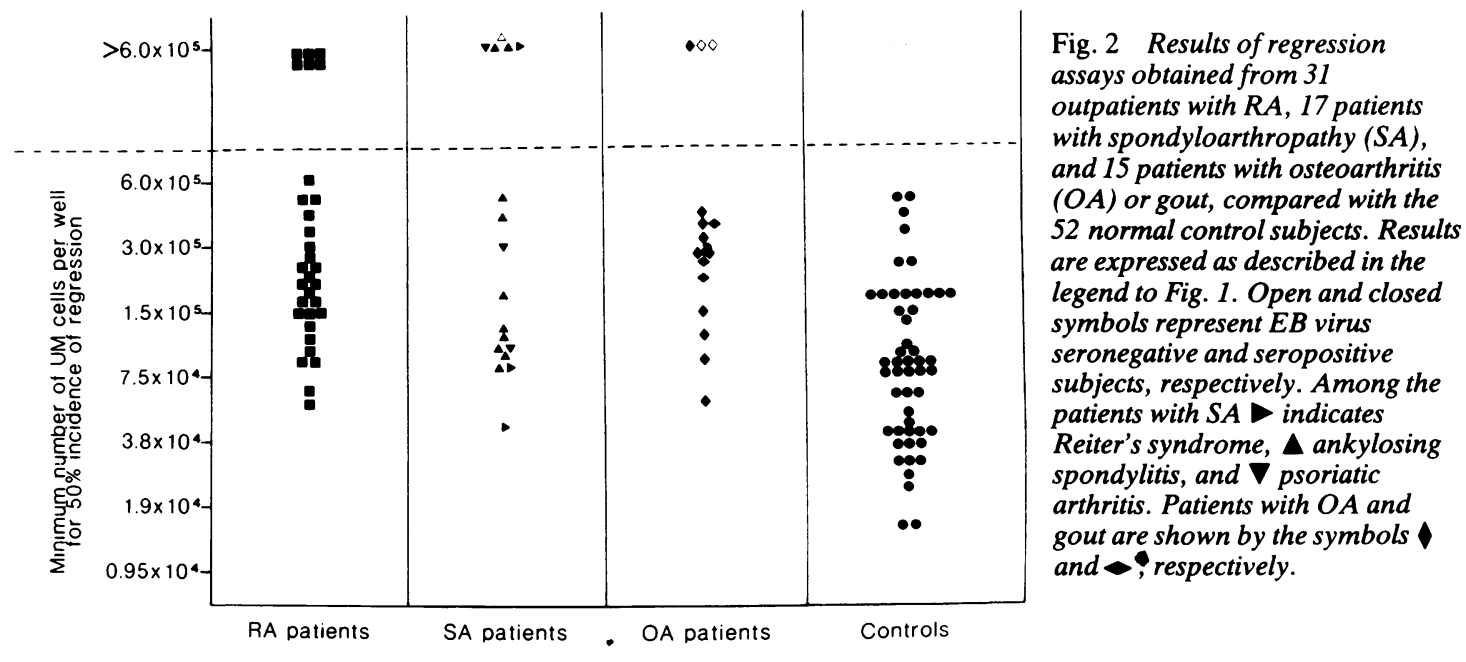

Fig. 2 Results of regression assays obtained from 31 vatients with osteoarthritis are expressed as described in the legend to Fig. 1. Open and closed symbols represent $E B$ virus seronegative and seropositive subjects, respectively. Among the patients with $S A-$ indicates Reiter's syndrome, $\Delta$ ankylosing spondylitis, and $\nabla$ psoriatic arthritis. Patients with $O A$ and gout are shown by the symbols and $\rightarrow$ respectively. 
regression previously noted with certain RA patients, while, with the exception of a single subject, EB virus seropositive patients with osteoarthritis or gout had a strength of regression within the range recorded for normal subjects. The second group of patients with RA also contained several individuals whose virus specific $T$ cell reactivity was clearly disturbed, though the proportion (six out of 31) was lower than that seen in the group of patients selected on the basis of active disease.

\section{Discussion}

The present study has extended the initial observation that patients with RA had a marked impairment in their ability to generate a cytotoxic $T$ cell response to $\mathrm{EB}$ virus ${ }^{15}$ by showing, firstly, that this impairment is related to the activity of disease in RA, and secondly, that a similar impairment may be observed in patients with other arthropathies. The first point was demonstrated by investigation of a group of patients with active RA who were treated with the disease modifying drug sulphasalazine. As in previous studies of this drug ${ }^{20}$ there was clear evidence of a response both by clinical and laboratory criteria (Table 1), and when the strength of the EB virus specific cytotoxic $T$ cell response was measured in these patients there was a significant increase in nine of the 14 patients tested. This included four patients in whom regression was undetectable before treatment. It is worth emphasising that such changes are not seen in normal individuals, who invariably show very stable levels of regression when tested repeatedly over several years. ${ }^{22}$ As additional evidence of a relation between disease activity and impaired regression, several other observations were informative: the incidence of patients with regression outside the normal range was higher in the group of RA patients with active disease (six of 14) than in the group seen routinely in outpatients and not taking disease modifying agents (six of 31), while in a further group of 10 patients hospitalised because of severe RA six had undetectable regression (unpublished results). Changes in regression together with disease activity were also striking in two particular patients: one (who presented with severe active disease including weight loss and lymphadenopathy) had undetectable regression initially, but showed regression in the normal range when he achieved and maintained a complete remission; a second patient who had regression in the normal range initially suffered a severe exacerbation of RA with widespread synovitis while taking sulphasalazine, and was then found to have undetectable regression. Finally, although a wide range in the strength of regression is seen in normal individuals, it is of interest that a significant correlation could still be found between the serum CRP (taken as a sensitive measurement of disease activity ${ }^{23}$ ) and the strength of regression measured before and after treatment.

The second group of experiments was designed to show whether the abnormal EB virus specific $T$ cell response seen in RA was peculiar to this disease or was also present in patients with other arthropathies. It was clear from the results that a number of patients with typical seronegative arthropathies also showed significantly impaired regression; since only a few patients were investigated and no prospective study performed a relation between disease activity and impairment could not be discerned, and this point will require further study. In contrast, almost all the patients with gout or osteoarthritis, attending the same clinic, had regression within the normal range (the single exception is unexplained but was a consistent finding in repeated assays).

The results of this study are relevant to the question of what relation, if any, exists between RA and EB virus infection. ${ }^{24}$ The most striking finding in this regard is still the presence of increased titres of antibodies to the RA associated nuclear antigen (RANA). This antigen seems to be an EB virus encoded nuclear antigen ${ }^{3-5}$ to which normal individuals do not usually make a significant antibody response. ${ }^{6}$ This apparently aberrant response in RA could be explained in two ways. On the one hand, an impairment in the immunological control of EB virus infection could result in an increase in the quantity of virus encoded proteins produced in vivo and available to elicit antibody responses. On the other hand, antibodies to RANA may represent an immune response to an unknown antigen which fortuitously cross reacts with an EB virus encoded protein, so that the unusual serological profile does not actually reflect altered antiviral surveillance. Although this study has shown, as have others, ${ }^{81} 14172526$ an abnormality in the cellular immune response to EB virus in patients with $\mathrm{RA}$, it is noteworthy that the virus-host balance is only minimally disturbed. ${ }^{17}$ Thus in comparison with immunosuppressed subjects, ${ }^{27} 28$ patients with RA show only slightly increased antibody titres to other EB virus specific antigens ${ }^{12}$ and a modest increase in the frequency of both EB virus infected $B$ cells in the circulation and detectable virus shedding in throat washings. ${ }^{17}$ The present observations indicating that the impairment in EB virus specific cytotoxic $T$ cell responses may only be intermittent, reflecting disease activity, would explain why no permanent alteration in the virus-host balance 
occurs in the majority of patients with RA. Viewed in this way, the unusual antibody response to RANA may well reflect reactivity directed against another, as yet unknown, antigen.

We are grateful to Dr P A Dieppe, Department of Medicine, Bristol Royal Infirmary, for permission to study the patients under his care, and for valuable discussion. We thank Elizabeth Gough for excellent technical help. This work was supported by the Cancer Research Campaign out of funds donated by the Bradbury Investment Company of Hong Kong, and was carried out while J S H Gaston was a Sir Michael Sobell Research Fellow of the Cancer Research Campaign.

\section{References}

1 Alspaugh M A, Henle G, Lennette E T, Henle W. Elevated levels of antibodies to Epstein-Barr virus antigens in sera and synovial fluids of patients with rheumatoid arthritis. $J$ Clin Invest 1981; 67: 1134-9.

2 Catalano M A, Carson D A, Slovin S F, Richman D, Vaughan $\mathrm{J}$ H. Antibodies to Epstein-Barr virus-determined antigens in normal subjects and in patients with seropositive rheumatoid arthritis. Proc Natl Acad Sci USA 1979; 76: 5825-8.

3 Alspaugh M A, Tan E M. Serum antibody in rheumatoid arthritis reactive with a cell-associated antigen. Demonstration by precipitation and immunofluorescence. Arthritis Rheum 1976; 19: 711-9.

4 Alspaugh M A, Jensen F C, Rabin H, Tan E M. Lymphocytes transformed by Epstein-Barr virus. Induction of nuclear antigen reactive with antibody in rheumatoid arthritis. J Exp Med 1978; 147: 1018-27.

5 Venables P J W, Roffe L M, Erhardt C C, Maini R N, Edwards J M B, Porter A B. Titres of antibodies to RANA in rheumatoid arthritis and normal sera. Arthritis Rheum 1981; 24: 1459-64.

6 Sculley T B, Walker P J, Moss D J, Pope J H. Identification of multiple Epstein-Barr virus-induced nuclear antigens with sera from patients with rheumatoid arthritis. J Virol 1984; 52: 88-93.

7 Thorley-Lawson D A, Chess L, Strominger J L. Suppression of in vitro Epstein-Barr virus infection. A new role for adult $T$ lymphocytes. J Exp Med 1977; 146: 495-508.

8 Bardwick P A, Bluestein H G, Zvaifler N J, Depper J M, Seegmiller J E. Altered regulation of Epstein-Barr virusinduced lymphocyte proliferation in rheumatoid arthritis lymphoid cells. Arthritis Rheum 1980; 23: 626-32.

9 Depper J M, Bluestein H G, Zvaifler N J. Impaired regulation of Epstein-Barr virus-induced lymphocyte proliferation in rheumatoid arthritis is due to a T cell defect. J Immunol 1981; 127: 1899-902.

10 Moss D J, Rickinson A B, Pope J H. Long term T-cell mediated immunity to Epstein-Barr virus in man. I. Complete regression of virus-induced transformation in cultures of seropositive donor leucocytes. Int J Cancer 1978; 22: 662-8.

11 Rickinson A B, Moss D J, Pope J H. Long-term T cell-mediated immunity to Epstein-Barr virus in man. II. Components necessary for regression in virus-infected leucocyte cultures. Int J Cancer 1979; 23: 610-7.

12 Moss D J, Rickinson A B, Pope J H. Long term T cell-mediated immunity to Epstein-Barr virus in man. III. Activation of cytotoxic $T$ cells in virus infected leucocyte cultures. Int $J$ ज Cancer 1979; 23: 618-25.

13 Rickinson A B, Moss D J, Pope J H, Ahlberg N. Long term T cell-mediated immunity to Epstein-Barr virus in man. IV. Development of cell memory in convalescent infectious mononucleosis patients. Int J Cancer 1980; 25: 59-65.

14 Tosato G, Steinberg A D, Blaese R M. Defective EBV-specific suppressor T cell function in rheumatoid arthritis. N Engl J Med के 1981; 305: 1238-43.

15 Gaston J S H, Rickinson A B, Epstein M A. Epstein-Barr virusspecific cytotoxic $T$ cell response in rheumatoid arthritis patients. Rheumatol Int 1982; 2: 155-9.

16 Ropes M W, Bennett G A, Cobb S. Diagnostic criteria for rheumatoid arthritis: 1958 revision. Ann Rheum Dis 1959; 18: 49-54.

17 Yao Q Y, Rickinson A B, Gaston J S H, Epstein M A. cे Disturbance of the Epstein-Barr virus-host balance in rheumatoid arthritis patients: a quantitative study. Clin Exp Immunol 1986; 64: 302-10.

18 Henle G, Henle W. Immunofluorescence in cells derived from Burkitt's lymphoma. J Bacteriol 1966; 91: 1248-56.

19- Martin M F R, Dieppe P A, Jones H E, Warren C, Whicher J. Serum concanavalin A binding in rheumatoid arthritis. Ann Rheum Dis 1982; 41: 133-6.

20 Bird H A, Dixon J S, Pickup M E, et al. A biochemical assessment of sulphasalazine in rheumatoid arthritis. $J$ Rheumatol 1982; 9: 36-45.

21 Bax D E, Amos R S. Sulphasalazine: a safe effective agent for prolonged control of rheumatoid arthritis. A comparison wit sodium aurothiomalate. Ann Rheum Dis 1985; 44: 194-8.

22 Rickinson A B, Moss D J, Wallace L E, et al. Long-term T-cel mediated immunity to Epstein-Barr virus. Cancer Res 1981; $4 \mathrm{~F}$ 4216-21.

23 Dixon J S, Bird H A, Pickup M E, Wright V. A human model screening system for the detection of specific anti-rheumatic activity. Semin Arthritis Rheum 1982; 12: 185-90.

24 Depper J M, Zvaifler N J. Epstein-Barr virus. Its relationship to the pathogenesis of rheumatoid arthritis. Arthritis Rheum 1981; 24: 755-61.

25 Moss D J, Klestov A, Burrows S, Kane R G. A comparison of Epstein-Barr virus-specific $T$ cell immunity in rheumatoid arthritis and osteoarthritis patients. Aust J Exp Biol Med Sci 1983; 61: 509-15.

26 Irving W L, Walker P R, Lydyard P M. Abnormal responses of rheumatoid arthritis lymphocytes to Epstein-Barr virus infection in vitro: evidence for multiple defects. Ann Rheum Dis 1985 ; 44: 462-7.

27 Gaston J S H, Rickinson A B, Epstein M A. Epstein-Barr virusspecific $T$ cell memory in renal allograft recipients under longterm immunosuppression. Lancet 1982; i: 923-5.

28 Yao Q Y, Rickinson A B, Gaston J S H, Epstein M A. In vitro analysis of the Epstein-Barr virus:host balance in long term renal allograft recipients. Int J Cancer 1985; 35: 43-9. 